\title{
New data on Chloropidae (Diptera: Cyclorrhapha) from Cyprus
}

\section{Новые данные о змаковых мухах Chloropidae (Diptera: Cyclorrhapha) острова Кипр}

\author{
Emilia P. Nartshuk \\ Э.П. Нарчук
}

Zoological institute of the Russian Academy of Sciences, Universitetskaya nab.1, St. Petersburg 199034, Russia. E-mail: chlorops@zin.ru Зоологический институт Российской Академии Наук, Университетская наб.1, Санкт-Петербург 199034, Россия. E-mail: chlorops@zin.ru

KEY WORDS: Diptera, Chloropidae, Cyprus, new faunistic data.

КЛЮЧЕВЫЕ СЛОВА: Diptera, злаковые мухи, Кипр, новые фаунистические данные.

ABSTRACT. A small collection of Chloropidae from Cyprus in Zoological Museum in Copenhagen contains 6 species. A species Oscinimorpha novakii (Strobl, 1893) is added to the fauna of Cyprus. Drawing of male genitalia of Anacamptoneurum obliquum Becker, 1903 illustrated for the first time. Analysis of distribution of all known Chloropidae fauna of Cyprus is done.

РЕЗЮМЕ. Небольшая коллекция злаковых мух с Кипра в коллекции Зоологического музея Датского Университета в Копенгагене включает 6 видов, из них один Oscinimorpha novakii (Strobl, 1893) впервые найден на Кипре. Впервые иллюстрированы гениталий самца Anacamptoneurum obliquum Becker, 1903 и дан анализ распространения всех видов, известных на Кипре.

\section{Introduction}

There are two publications with the data of Chloropidae fauna of Cyprus [Georghiou, 1977; Nartshuk, 1990]. Nineteen species were recorded and for three other only generic affiliation was done. I have opportunity to identify a small Chloropid collection from Cyprus in Zoological Museum of Denmark University in Copenhagen. Collection contains 43 specimens collected by B. Petersen in 1983. Six species were found, one of them records for the first time on Cyprus, for other new localities are recorded.

\section{List of species}

\section{Subfamily Rhodesiellinae}

1. Scoliophthalmus trapezoides Becker, 1903.

MATERIAL. $3 \sigma^{\top} \sigma^{7}, 4$ 우, Ayia Napa, $10 \mathrm{~km}$ W Capo Greco, 13-23.06.1983.

Only a female was recorded earlier (specimen in Natural history museum in Helsinki) [Nartshuk, 1990]. Examination of male genitalia confirms preceding record. Species known in Egypt, Israel and the Afrotropical Region.

\section{Subfamily Oscinellinae}

2. Anacamptoneurum obliquum Becker, 1903.

MATERIAL. $1 \mathrm{O}^{\top}, 8$ 우, Ayia Napa, $10 \mathrm{~km}$ W Capo Greco, 1323.06.1983.

Species was described from Egypt, known in Israel, Cyprus, Middle Asia and the Afrotropical Region. Male genitalia of the species is illustrated (Figs 1-3).

3. Oscinella frit (Linnaeus, 1758).

MATERIAL. 1 \%, Troodos Mts., 1400-1800 m, 12.06.1983.

Widely distributed in Holarctic, Afrotropical and Oriental Regions. Well known pest of cereals.

\section{Oscinimorpha novakii (Strobl, 1893).}

MATERIAL. 3 우, Troodos Mts., 1400-1800 m, 12.06.1983; 1 , Ayia Napa, $10 \mathrm{~km} \mathrm{~W}$ Capo Greco, 13-23.06. 1983.

New species for fauna of Cyprus. Widely distributed south palaearctic species, known from micronesian and mediterranean subregions, from the Canaries through southern Europe to Israel.

\section{Tricimba humeralis Loew, 1858.}

MATERIAL. 4 o', 12 우, Ayia Napa, 10 km W Capo Greco, 13-23.06. 1983.

All specimens are light coloured: frons yellow, except grey ocellar triangle, postpronotum, propleura, and prosternum yellow, scutellum yellow with small grey basal spot, legs and all setae and setulae yellow.

Species wide spread in the Palaearctic from the Azores and the Canaries to Mongolia, in Europe to North to southern Sweden, and in the Afrotropical Region (Sudan).

\section{Subfamily Chloropinae}

6. Assuania thalhammeri (Strobl, 1893).

MATERIAL. 107, 8 + 9 , Ayia Napa, 10 km W Capo Greco, 1323.06.1983.

Widely distributed in southern Palaearctic from Spain to Afghanistan, and North Africa (Algeria, Egypt). 


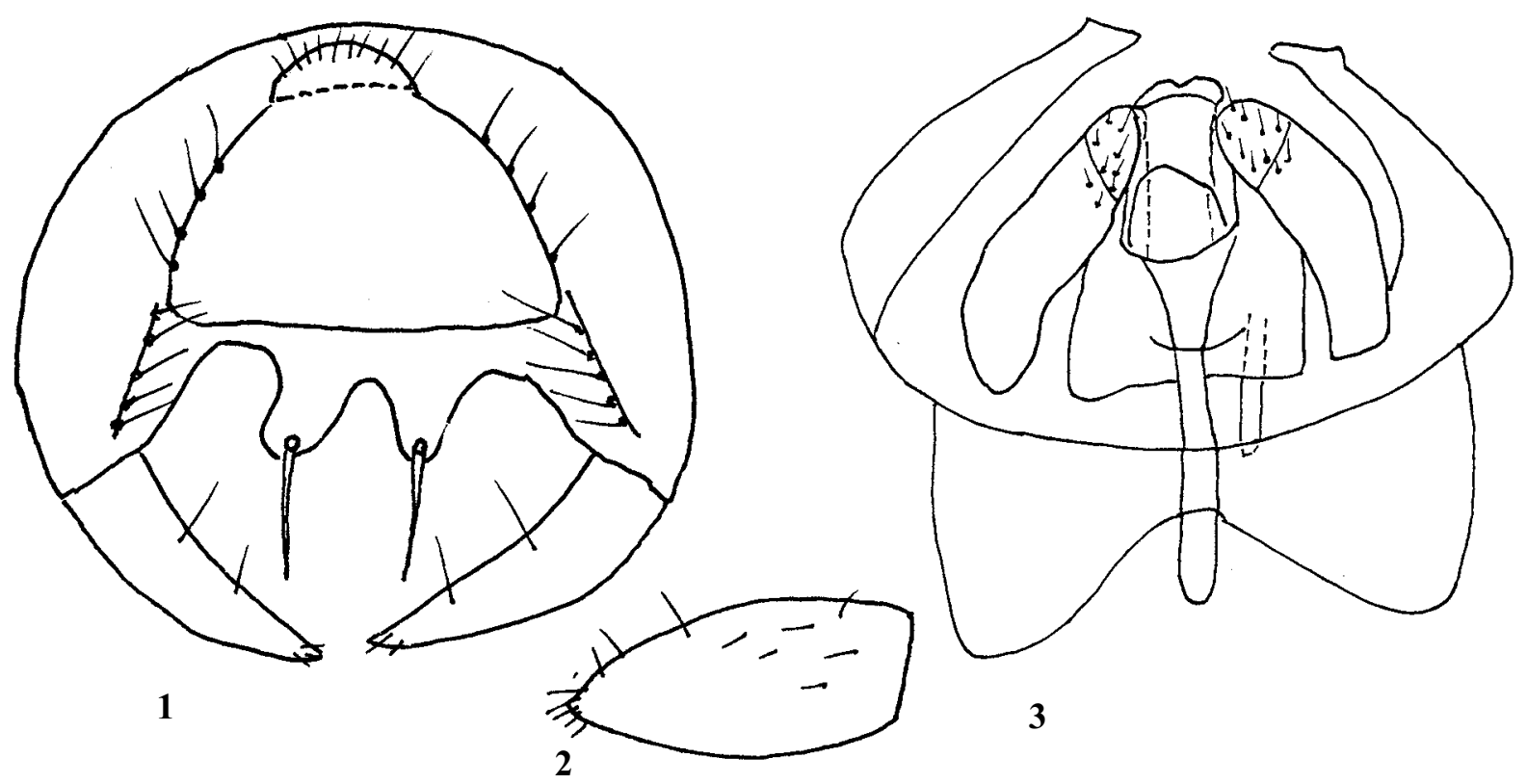

Figs 1-3. Anacamptoneurum obliquum Becker, 1903, male genitalia: 1 - epandrium, posterior view; 2 - surstylus; 3 — hypandrium, ventral view.

Рис. 1-3. Anacamptoneurum obliquum Becker, 1903, половой аппарат самца: 1 - эпандриум, вид сзади; 2 - сурстиль; 3 гипандриум, вид снизу.

\section{Conclusions}

Up to now 20 species of Chloropidae are recorded on Cyprus. Chloropidae fauna of Cyprus contain following zoogeographical elements.

Multiregional (Palaearctic, Oriental, Afrotropical): Oscinella frit, Siphunculina ornatifrons (Loew, 1858), Thaumatomyia notata (Meigen, 1830); MediterraneanAfrotropical: Anacamptoneurum obliquum, Scoliophthalmus trapezoides, Tricimba humeralis; Transpalaearctic: Thaumatomyia rufa (Macquart, 1835), Conioscinella frontella (Fallén, 1820); South-Palaearctic-Mediterranean: Polyodaspis sulcicollis (Meigen, 1838), Assuania thalhammeri, Thaumatomyia sulcifrons (Becker, 1907); European-Mediterranean:Elachiptera bimaculata (Loew, 1845), E. megaspis (Loew, 1858), Oscinimorpha arcuata (Duda, 1932), O. nivakii, Camarota curvipennis (Latreille, 1805); Mediterranean: Aphanotrigonum favillaceum (Becker, 1903), Trachysiphonella pori Harkness et Ismay, 1976, Tricimba meridiana DelyDraskovits, 1983, Speccafrons cypria Nartshuk, 1990.
Main body of species distributed in South Europe/Palaearctic and Mediterranean subregion of the Palaearctic.Three spesies Anacamptoneurum obliquum, Scoliophthalmus trapezoides, and Siphunculina ornatifrons demonstrate connection with Afrotropical fauna. A species Speccafrons cypria is known only from Cyprus.

ACKNOWLEDGEMENTS. My sincerely thanks to Dr Th. Pape for opportunity to visit the Zoological Museum of Denmark University in Copenhagen and work with the Diptera collection. Financial support from the Russian Foundation for Basic Research (grants 08-04-00186), Programmes of the Presidium of the Russian Academy of Sciences "Scientific bases of conservation of biodiversity in Russia" and "Origin and Evolution of Biosphere".

\section{References}

Georghiou G.P. 1977. The insects and mites of Cyprus // Kiphissia. Athens, Greece. 347 pp.

Nartshuk E.P. 1990. Chloropid flies (Diptera, Chloropidae) of Cyprus // Entomologica Fennica. No.1. P.227-232. 